I.B.Попова, кандидат технічних наук, доичент НУXТ

\title{
ВПРОВАДЖЕННЯ СПЕЦІАЛЬНОЇ ЕКОЛОГІЧНОЇ ОСВІТИ - СОЦІАЛЬНЕ ЗАВДАННЯ МОДЕРНІЗАЦІї ОСВІТНЬОГО ПРОЦЕСУ
}

Упродовж тисячоліть з моменту появи Homo sapiens культивувалося споживацьке ставлення до природи, іiі природних ресурсів. Вважали, що природна комора цих ресурсів невичерпна, а тому їх можна необмежено споживати для задоволення всезростаючих потреб. Так тривало майже до наших днів. I тільки наприкінці XIX на початку XX ст., коли чисельність населення почала катастрофічно зростати, а ресурси, які природа накопичувала мільйони й мільярди років, почали стрімко вичерпуватись, людство збагнуло, що природні ресурси в біосфері вичерпні, а деякі з них уже нині перебувають на межі зникнення.

У науковому світі питаннями впровадження екологічної освіти, модернізації освітнього процесу розглядали багато дослідників, серед них 3. Плохій, Д. Маркович, Г.Бєлєнька та багато інших.

Стало очевидним, що «ресурси, які потрібні для підтримки людського життя на землі, скорочуються 3 величезною швидкістю» $[1,2]$. Тому найголовнішим завданням сучасної епохи вважається формування нової екологічної свідомості, «вищого психічного відображення природного, штучного і соціального середовища i свого внутрішнього світу; рефлексія місця і ролі людини в екологічному світі, а також саморегуляція цього відображення» $[1,91]$.

Надзвичайно важливим і актуальним є вирішення проблеми ефективного захисту навколишньої природи від забруднення техногенними розсіюваними й неутилізованими відходами та проблеми раціонального використання природних ресурсів.

Для подолання екологічної кризи у кожній країні у Державній програмі охорони навколишнього природного середовища, раціонального використання природних ресурсів і екологічної безпеки має передбачатися запровадження загальної екологічної освіти та виховання. Вона повинна охопити всі верстви населення, починаючи 
від дитячого садка і закінчуючи вищою школою.

Основним завданням екологічної освіти та виховання в країні мають бути формування екологічної свідомості щодо гармонійного співіснування людського суспільства 3 навколишнім природним середовищем та охорона останнього від техногенних забруднень. На це повинні бути спрямовані вся структура, зміст і методи навчання. Освіта й виховання повинні організовуватись на чотирьох рівнях: загальна (для всього населення країни), дошкільна (для дітей дошкільного віку), шкільна і вища.

Метою загальної освіти, насамперед, має бути формування екологічного світогляду, прищеплення любові до рідного краю, розуміння необхідності охорони навколишнього природного середовища на роботі та в побуті, навичок бережливого й раціонального споживання природних ресурсів, прагнення до відтворення відновних природних ресурсів i обгрунтованого самообмеження використання невідновних, створення ефективної системи екологічної безпеки. Загальна освіта, таким чином, перетворюється на екологічну освіту, яка, за висловом І.В.Книш, являє собою «комплексний процес, який розглядається в літературі в різних аспектах: соціологічному, економічному, освітньому або як складова гуманістичного світогляду, де перш за все виокремлюється його екологічний компонент» $[2,109]$.

Дошкільна екологічна освіта має бути спрямована на прищеплення любові до Вітчизни та рідного краю, пізнання понять життя і смерті, формування навичок бережливого ставлення до навколишньої природи, прагнення зберегти рослинний і тваринний світ, зробити кращим навколишнє природне середовище. «Адже, на думку В.Сухомлинського, природа лежить в основі дитячого мислення, почуттів та творчості. Він вважав, що формувати в дитини дошкільного віку ставлення до рідного краю як частки природи слід починати з раннього віку» $[3,16]$.

Шкільна екологічна освіта повинна мати на меті вивчення основ загальної екології, раціонального використання природних ресурсів та екологічної безпеки біосфери на рівні викладання дисциплін біології, хімії, фізики та географії в середній школі.

Метою екологічної освіти у вищій школі має бути підготовка фахівців вищої кваліфікації (вчителів, викладачів, інженерів, магістрів, кандидатів і докторів наук) для організації суспільного життя 
і виробництва, проведення наукових досліджень у галузі екології, тобто вирішення повсякденних екологічних завдань і глобальних екологічних проблем. Тут потрібно фундаментально вивчати загальну теоретичну та прикладну екологію (охорону природи, раціональне природокористування та екологічну безпеку біосфери).

Та ефективність національної екологічної освіти залежатиме від ряду факторів, серед яких одне з головних місць належить вибору педагогічних технологій, методів та окремих прийомів. Тому, як зазначає О.Н. Фомичев, «особливого значення має набути підготовка спеціалістів у сфері екології як проблемній та актуальній галузі сучасного знання» [4, 186-187].

Однією із перспективних і дієвих педагогічних технологій навчання основ екології є сопроективна. Стратегія даної технології полягає у співпраці учителя й учня на рівні проективної діяльності. Реалізація спільного проекту формує в учнів уміння висувати екологічно обгрунтовані гіпотези, пропозиції, робити узагальнення, критично ставитись до екологічної інформації, в результаті чого школярі навчаються передбачати очікувані наслідки, усувати негативні причини, дотримуватись безпечної поведінки, приймати спільне рішення.

Сучасними засобами в реалізації екологічної освіти є застосування мультимедійних технологій, зокрема навчальних комп'ютерних технологій, що сприяє навчанню школярів моделюванню екологічних ситуацій, опрацюванню результатів спостереження, що значно розширюватиме кругозір, зблизить навчання 3 життям, надасть інформацію про проблеми взаємодії між людьми й навколишнім середовищем.

Організаційно-діяльнісній педагогічній технології належить першорядне місце щодо чіткої, поетапної системи екологічної підготовки учнів. Стратегією цієї технології $€$ формування емоційноціннісної сфери (мотивації екологічно-безпечної поведінки, зацікавленості у вивченні екологіі).

Впровадження особистісно орієнтованої педагогічної технології відіграє провідну роль у формуванні громадянської відповідальності школярів, гуманного і дбайливого ставлення до сусідів по планеті; виробляє наполегливість, стриманість у бажаннях, самооцінювання своїх вчинків. Методика такої технології грунтується на індивідуальному підході до кожного учня, урахуванні навчальних 
можливостей, темпу навчання, здібностей. Основною ідеєю є розвивальний підхід, тобто не надання вчителем готових знань 3 екології, а навчання умінню іiі здобувати та переносити в реальні життєві ситуації.

Такі технології грунтуються на інтерактивному (діалоговому) навчанні, коли у процесі діалогу або полілогу вчитель спонукає учня до спільної діяльності.

Згідно з Національною доктриною розвитку освіти, «Україна визнала освіту однією з пріоритетних галузей, тобто держава взяла на себе обов'язок забезпечити іiі прискорений, випереджальний, інноваційний розвиток. Ці заходи включають істотне зміцнення навчально-матеріальної бази, здійснення комп'ютеризації навчальних закладів, впровадження освітніх інновацій, інформаційних технологій, органічне поєднання освіти і науки, інтеграцію їх до європейського та світового науково-освітнього простору. Національна доктрина розвитку освіти передбачає як основний шлях модернізацію української освіти на найближчі 25 років і головною метою державної політики в освіті проголошує створення необхідних умов для розвитку життя» [5, 2-3].

В доктрині сказано, що державна політика в галузі екологічної освіти повинна базуватися на таких принципах:

- поширення системи екологічної освіти і виховання на всі верстви населення з урахуванням індивідуальних інтересів, стимулів та особливостей соціальних, територіальних груп та професійних категорій;

- комплексність екологічної освіти і виховання;

- неперервність процесу екологічного навчання в системі освіти, в тому числі підвищення кваліфікації та перепідготовки.

Основною метою екологічної освіти є формування екологічної культури окремих осіб і суспільства в цілому, формування навичок, фундаментальних екологічних знань, екологічного мислення і свідомості, що грунтуються на ставленні до природи як універсальної, унікальної цінності. Екологічна освіта, з одного боку, повинна бути самостійним елементом загальної системи освіти, і з іншого, - виконує інтегративну роль в усій системі освіти.

Ця мета досягається поетапно шляхом вирішення освітніх $\mathrm{i}$ виховних завдань та вдосконалення практичної діяльності.

Найголовнішими завданнями екологічної освіти мають бути: 
1. Формування екологічної культури всіх верств населення, що передбачає:

- виховання розуміння сучасних екологічних проблем держави й світу, усвідомлення їх важливості, актуальності і універсальності (зв'язку локальних з регіональними і глобальними);

- відродження кращих традицій українського народу у взаємовідносинах $з$ навколишнім середовищем, «виховання любові до рідної природи» $[6,12]$;

- формування усвідомлення безперспективності технократичної ідеї розвитку й необхідності заміни іiі на екологічну, яка базується на розумінні єдності всього живого й неживого в складноорганізованій глобальній системі гармонійного співіснування й розвитку;

- формування розуміння необхідності узгодження стратегії розвитку природи і стратегії розвитку людини на основі ідеї універсальності природних зв'язків та самообмеженості, подолання споживацького ставлення до природи;

- розвиток особистої відповідальності за стан навколишнього середовища на місцевому регіональному, національному і глобальному рівнях, вміння прогнозувати особисту діяльність і діяльність інших людей та колективів;

- розвиток уміння приймати відповідальні рішення щодо проблем навколишнього середовища, оволодіння нормами екологічно грамотної поведінки; виховання глибокої поваги до власного здоров'я та вироблення навичок його збереження;

2. Підготовка фахівців-екологів для різних галузей народного господарства, в тому числі:

- д для освітньої галузі $\square$ вчителів, викладачів;

- для державних органів управління в галузі охорони навколишнього середовища та раціонального природокористування, а також громадських екологічних організацій.

3. Вдосконалення, узгодження і стандартизація термінології в галузі екологічних знань.

В основу екологічної освіти повинні бути покладені «принципи гуманізму» [7, 342], науковості, неперервності, наскрізності та систематичності.

Екологічна освіта повинна спрямовуватися на поєднання раціонального й емоційного у взаємовідносинах людини з природою 
на базі принципів добра й краси, розуму й свідомості, патріотизму й універсалізму, наукових знань і дотримання екологічного права.

Екологічна освіта - це сукупність таких компонентів: екологічні знання - екологічне мислення - екологічний світогляд - екологічна етика - екологічна культура. Кожному компоненту відповідає певний рівень екологічної зрілості: від елементарних екологічних знань, уявлень дошкільного рівня до їх глибокого усвідомлення і практичної реалізації на вищих рівнях. Умовно можна виділити наступні узагальнені рівні екологічної зрілості: початковий (інформативно-підготовчий), основний (базово-світоглядний), вищий, профільно-фаховий (світоглядно-зрілий).

«Провідними методами екологічної освіти, на думку 3. Плохія, мають бути: спостереження, експериментування, моделювання, продуктивна діяльність, розв'язання проблемних ситуацій, педагогічне спілкування» [8, 6-7].

Основними стратегічними напрямками розвитку екологічної освіти є:

- розробка наукових основ неперервної екологічної освіти на основі Національної доктрини розвитку освіти у XXI ст., здобутків української та зарубіжної педагогічної практики за участю Академії педагогічних наук України, провідних вчених і практиків освітньої галузі, Міністерства екології та природних ресурсів України, громадських екологічних організацій;

- поетапне реформування екологічної освіти та виховання особистості на наукових і духовних принципах з урахуванням національних традицій, надбань та світового досвіду;

- формування поколінь з новою екологічною культурою, новим екологічним світоглядом на принципах гуманізму, міждисциплінарної інтеграції, історизму та системності з метою збереження і відновлення природи України та їі біологічного різноманіття;

- сприяння відновленню екологічної компетентності, яка «має діяльнісний характер і передбачає здатність мобілізувати знання, ставлення дитини, готовність реалізувати їх у конкретній екологічній ситуації» $[9,7]$.

- розвиток міжнародних зв’язків і співробітництва у галузі екологічної освіти і науки, охорони навколишнього середовища, раціонального використання природних ресурсів, збереження біосфери та цивілізації. 
Головними тактичними завданнями мають бути:

- розробка й постійне вдосконалення державних стандартів професійної екологічної освіти та удосконалення діючих стандартів усіх рівнів і напрямів підготовки та виховання з урахуванням вимог щодо формування екологічної культури;

- підготовка, підвищення кваліфікації й перепідготовка викладачів екологічних дисциплін з врахуванням нових підходів, організація екологічних семінарів і курсів, організація центрів перепідготовки тощо;

- розробка й видання якісної навчальної літератури з екології (підручників, посібників, довідників, словників, методичних розробок) для шкіл, ПТУ, коледжів, технікумів і вищих навчальних закладів, розробка й видання екологічної літератури для дітей дошкільного віку;

- розробка екологічних радіо- і телепрограм, підготовка й організація систематичних показів по телебаченню навчальних, наукових і науково-популярних екологічних фільмів;

- залучення громадських екологічних організацій, просвітницьких товариств до поширення екологічних знань та елементів екологічної культури серед широких верств населення;

- започаткування програми підвищення кваліфікації та перепідготовки державних службовців, керівного складу підприємств, організацій, установ, підприємців, які мають право і можливість приймати екологічно значущі рішення у сфері практичної діяльності.

Реалізація даних напрямків екологічної освіти забезпечується шляхом вирішення конкретних завдань:

- термінова розробка Державного стандарту вищої освіти різних рівнів за напрямом «Екологія»;

- включення до Державних стандартів шкільної, професійнотехнічної та вищої освіти різних рівнів за всіма напрямами, які забезпечують екологізацію навчальних програм, зокрема:

- включення до інваріативної частини шкільного компонента школи третього ступеня навчальної дисципліни «Основи екологічних знань»;

- включення до освітньо-професійних програм підготовки молодшого спеціаліста та бакалавра нормативної дисципліни «Основи екології»;

- введення спеціального розділу з охорони навколишнього 
середовища та раціонального природокористування у дипломні (кваліфікаційні) роботи (проекти) випускників технічного, аграрного, військового та інших напрямів підготовки;

- створення при Міністерстві освіти і науки України та обласних органах державної влади Координаційних міжгалузевих рад 3 екологічної освіти із залученням зацікавлених міністерств та відомств, основною функцією яких є впровадження цієї концепції на державному та регіональному рівнях, координація формування державних стандартів екологічної освіти, навчальних програм та підготовка підручників, посібників з екології тощо; створення та впровадження системи дистанційного навчання за різними програмами екологічної освіти на базі провідних ВНЗ екологічного спрямування;

- організація за рішенням Координаційних рад обласних центрів підвищення рівня екологічної освіти працівників освіти та підготовка фахівців у даній галузі. Виконання даного завдання передбачає реалізацію в педагогічному процесі підходів, які «забезпечують формування «людини-культури», тобто такої, що поєднує в собі культуру мислення, мови, поведінки, праці, почуттів» $[10,159]$;

- розробка й видання на конкурсній основі навчальних програм, підручників, посібників з екології для різних ланок освіти, в тому числі в електронному вигляді. Забезпечення постійного перекладу кращих зарубіжних підручників, посібників і монографій з екології;

- створення банку аудіовізуальних програм, слайдотек та науково-популярних фільмів у галузі охорони навколишнього середовища з відповідним програмним забезпеченням;

- створення інформаційної служби, яка б постійно і оперативно доводила достовірну екологічну інформацію до населення;

- 3 метою обміну досвідом і оперативного поширення новин в галузі екологічної освіти створити спеціальний часопис «Екологічна освіта»;

- створення в навчальних закладах всіх рівнів освіти сучасних екологічних лабораторій;

- створення ВНЗ з питань екології і природокористування у м. Києві;

- впровадження системи професійної підготовки керівників і державних службовців 3 «Основ екологічної політики і управління»;

- розробка і тиражування екологічних комп'ютерних імітаційних ігор для різних ланок освіти; 
- створення й реалізація в найближчі роки радіо- і телевізійних екологічних програм з основних екологічних проблем держави;

- видання популярної літератури, коміксів з екологічної та природоохоронної тематики для дітей;

- створення національного банку інформації з екологічної освіти і виховання, які мають колекціонувати типові і спеціальні навчальні і робочі навчальні плани з усіх екологічних дисциплін (як фундаментальних, так і вибіркових), програми, дані про посібники, методичні праці і підручники з екології, постанови Уряду і Міністерств, що стосуються розвитку екологічної освіти, міжнародні рішення і угоди, інформацію про конференції і семінари $з$ екологічної освіти тощо.

Реалізація цих завдань покликана поліпшити рівень екологічної свідомості суспільства, сприяти переходу України до гармонійного розвитку національної системи і призвести до встановлення екологічно безпечного зв'язку між людиною та природою.

\section{ЛІТЕРАТУРА}

1. Мелманн Мерілін. Якщо ми можемо мріяти про щось, можемо це здійснити // Освітні коментарі: щомісячник. - 2011. - №7/9. - С.2-4.

2. Ковальчук М.А. Формування екологічної свідомості фахівців через принцип неперервності екологічної освіти // Екологічна освіта і виховання: досвід та перспективи. - К., 2001. - С. 109-111.

3. Плохій 3. Екологічне світобачення дошкільнят // Дитячий садок. - Липень. Число - 2009. - №27(507). - С. 15-18.

4. Фомичев А.Н. Экологические доминанты современной науки и проблема экологического образования // Экология, культура, образование. (материалы к конференции). - М., 1989. - С. 184-188.

5. Національна доктрина розвитку освіти // Освіта. - 2002. - № 26 (24 квітня - 1 травня). - С.2-4.

6. Марушевський Г.Б. Етика збалансованого розвитку. - К., 2008. -430 с.

7. Маркович Данило. Социальная экология и экономическое образование // Ученые записки. - М., 1998. - С. 12-18.

8. Плохій 3. Еколого-розвивальне середовище дошкільного навчального закладу (інноваційні підходи) // Дошкільне виховання. - 2010. - №7. C. 6-10.

9. Бєлєнька Г. Дошкільнятам про світ природи: старший дошкільний вік. - К., 2013. - 112 с. 
10. Мамедов Н.М. Основания экологического образования // Философия экологического образования. - М., 2003. - С. 72-88.

\section{Попова І.В. Впровадження спеціальної екологічної освіти - сочіальне} завдання модернізації освітнього процесу.

Ще донедавна суспільний розвиток і регенерація навколишнього природного середовища перебували у динамічній рівновазі. Проте останніми роками, незважаючи на колосальні екологічні резерви біосфери та їі самоочисну спроможність, інтенсивне зростання чисельності населення планети, бурхливе піднесення промисловості, сільського й комунального господарства та інші антропогенні чинники призвели до різкого негативного впливу на природу. Насамперед це стосується забруднення біосфери хімічними речовинами-ксенобіотиками, порушення природних геохімічних циклів, а також інтенсивного, нераціонального використання природних ресурсів. Тому сьогодні надзвичайно актуальним $\epsilon$ формування нової екологічної свідомості громадян. А запровадження спеціалізованої екологічної освіти має сприяти генеруванню їх екологічного світогляду, прищеплювати їм любов до рідного краю, виробляти навички бережливого й раціонального споживання природних ресурсів і спрямовувати на створення ефективної системи екологічної безпеки.

Ключові слова: модернізація освіти, екологічна освіта, педагогічні технології.

Попова И.В. Внедрение специального экологического образования сочиальное задание модернизации образовательного прочесса.

Еще недавно общественное развитие и регенерация окружающей среды находились в динамическом равновесии. Однако в последние годы, несмотря на колоссальные экологические резервы биосферы и ее самоочищающуюся способность, интенсивный рост численности населения планеты, бурный подъем промышленности, сельского и коммунального хозяйства и другие антропогенные факторы привели к резкому негативному влиянию на природу. Прежде всего, это касается загрязнения биосферы химическими веществами-ксенобиотиками, нарушения природных геохимических циклов, а также интенсивного, нерационального использования природных ресурсов. Поэтому сегодня чрезвычайно актуальным является формирование нового экологического сознания граждан. А введение специализированного экологического образования должно способствовать генерированию их экологического мировоззрения, привитию им любви к родному краю, выработке навыков бережного и рационального потребления природных ресурсов и созданию эффективной системы экологической безопасности. 
Ключевые слова: модернизация образования, экологическое образование, педагогические технологии.

Popova I. Introduction of special environmental education - social task of modernization of the educational process.

Until recently, social development and regeneration of the environment were in dynamic equilibrium.However, in recent years, despite the enormous ecological reserves of biosphere and its self-cleaning ability, extensive growth of world population, rapid growth of industry, agriculture and municipal services and other anthropogenic factors have led to a dramatic negative impact on nature.First of all it concerns the pollution of the biosphere with chemicals xenobiotics, violation of natural geochemical cycles and intense, irrational use of natural resources. Today, therefore, extremely important is the formation of a new environmental consciousness of citizens. The introduction of specialized environmental education should promote to generation of environmental worldview, to instil in them a love for their land, produce lean skills and rational use of natural resources and lead to the creation of an effective system of environmental safety.

Key words: modernization of education, environmental education, pedagogical technologies. 